\title{
Rereading Comprehension Pedagogies: Toward a Dialogic Teaching Ethic that Honors Student Sensemaking
}

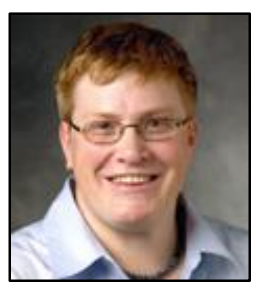

\section{Maren Aukerman}

Stanford University, USA

\begin{abstract}
This conceptual essay critiques reading comprehension pedagogies that are part of the current educational landscape. I argue that comprehension pedagogy generally reflects one of three differing orientations, each with its own assumptions about what comprehension is: comprehension-as-outcome pedagogies, which emphasize getting textual meaning "right"; comprehension-as-procedure pedagogies, which emphasize knowing the "right" ways doing reading; and comprehension-as-sensemaking pedagogies, which take all textual interpretation seriously, regardless of "rightness." Comprehension-as-sensemaking pedagogies, in turn, can be distinguished as either primarily responsive - aimed at surfacing student understandings - or primarily dialogic - aimed at getting student understandings to refract. Arguably, comprehension-as-outcome pedagogy dominates current reading instruction. A focus on measuring and teaching toward "right" interpretations permeates almost all aspects of comprehension pedagogy even when one of the other orientations toward comprehension pedagogy is also at play. While seemingly intuitive, this overarching outcome emphasis reifies textual meaning in ways that are both theoretically and ethically problematic. I make the case that comprehension-as-sensemaking pedagogy should become primary instead. I propose that comprehension-as-outcome and comprehension-as-procedure pedagogies should not be abandoned, but should be subordinated to dialogic comprehension-as-sensemaking pedagogy so that students' textual sensemaking is more fully heard, respected, and examined in reading classrooms.
\end{abstract}

Keywords: Dialogism; Reading Comprehension; Sensemaking; Theories of Reading; Ethics; Understanding

Maren Aukerman, a former bilingual classroom teacher, is an assistant professor of Curriculum and Teacher Education at the Stanford Graduate School of Education. She is the recipient of a National Academy of Education/Spencer Postdoctoral Fellowship, which helped support this research, and also received the 2009 Albert J. Harris Award for her Research in the Teaching of English article: "When reading it wrong is getting it right: Shared evaluation pedagogy among struggling fifth grade readers." Her research focuses on how students make meaning from text in conversation with others, and how teachers can better facilitate talk that makes authentic room for student voices. She can be contacted at: Stanford Graduate School of Education, 485 Lasuen Mall, Stanford, CA 94305-3096. Email: aukerman@stanford.edu 


\title{
Rereading Comprehension Pedagogies: Toward a Dialogic Teaching Ethic that Honors Student Sensemaking
}

\author{
Maren Aukerman \\ Stanford University
}

"Children are taught to read so they can understand what is in text. Thus, most of what matters in reading instruction matters because ultimately it affects whether the student develops into a reader who can comprehend what is in text. Reading instruction is effective in stimulating student comprehension abilities to the extent that it stimulates students to process texts as good readers do." (Pressley, 2000, p. 545)

"Meaning making is always creative; it is a surprise. It is a possibility among many other possibilities, and therefore never pre-determined." (Matusov, 2009, p. 2)

If reading is about the making of meaning with from text, what we make of that meaning-making is pivotal to our understanding of reading pedagogy. From Pressley's common-sense perspective, meaning-making is a standard way of engaging with text; consequently, teaching reading comprehension is about enhancing children's abilities so that they can become "good readers." Matusov, by contrast, has a less fixed view: following Bakhtin, he posits meaning-making as a "surprise" that cannot be predetermined. In the paper that follows, I argue that how educators treat reading comprehension pedagogy rests on varied assumptions about what comprehension means, assumptions embodied in three pedagogical orientations. ${ }^{1}$ These include comprehension-as-outcome pedagogy, which emphasizes getting the meaning "right", comprehension-as-procedure pedagogy, which emphasizes doing the "right" kind of reading, and comprehension-as-sensemaking pedagogy, which values the actual (creative, surprising) meanings readers make of text, regardless of "rightness" (Aukerman, 2008). This last orientation can be further divided between what I term expressivist comprehension-as-sensemaking pedagogy, which emphasizes surfacing student interpretations, and dialogic comprehension-assensemaking pedagogy, which seeks to juxtapose and engage with student's varying understandings through dialogue.

While each of the orientations plays some role in how reading is currently taught, I argue that comprehension-as-outcome pedagogies predominate. I further suggest that, no matter how appealing these pedagogies are, there are theoretical and ethical grounds for rejecting a primary focus on having students achieve "right" understandings of texts. I propose that reading educators and researchers should strive instead to make a dialogic comprehension-as-sensemaking pedagogy the fundamental engine - and ethic - for reading instruction. I make the case that, although there is a continued place for attending to comprehension-as-outcome and comprehension-as-procedure, these should be subordinated to a focus on engaging with students' sensemaking.

\footnotetext{
${ }^{1}$ These traditions are ones I have identified as primary based on my decades-long engagement with schools and with educational research literature, first as a reading teacher and later also as a scholar. I do not mean to imply that they represent the full range of ways that reading comprehension has been conceptualized, nor that schools and educational regimes universally privilege those pedagogical orientations I have identified here as primary.
} 


\section{Commonly Enacted Comprehension Pedagogies}

Reading researchers and practitioners have historically relied upon one term, comprehension, to denote multiple aspects of a complex intellectual endeavor, often without defining the term (e.g., National Reading Panel, 2000). An additional complicating factor is that a number of classroom practices also focusing on textual meaning-making have not been called comprehension (e.g., Wolf, Carey, \& Mieras, 1996). I will draw here on multiple pedagogical traditions that place an emphasis on reading for meaning, whether or not these emphasize the term "reading comprehension" per se. Either way, they manifest the varied assumptions about comprehension I describe below. By including such practices in my analysis, I am better able to map the range of practices undertaken in the service of supporting readers' focus on textual meaning, without arbitrarily excluding those that use different terminology. For each pedagogical orientation, I will first provide an overview, then discuss some practices where that pedagogy is prominent.

\section{Comprehension-as-Outcome Pedagogy}

Comprehension-as-outcome pedagogy aims to produce readers who generate "correct" readings of texts: they "get it." Whether novice readers have comprehension, partial comprehension, or lack comprehension depends on whether their readings are considered the right ones by their teacher. A comprehension-as-outcome orientation can be seen in currently ubiquitous directive teacher questioning sequences, generally with corrective feedback. Teachers who are concerned with students arriving at a predetermined textual understanding often organize classroom instruction around questions that primarily assess whether students have reached that sought-after understanding (or they give them written assignments with the same purpose).

A predominant emphasis on comprehension-as-outcome was observed to be ubiquitous as early as 1978, in Durkin's (1978-79) classic observational study of reading and social studies lessons in grades 3 through 6 . Durkin found that, to the extent that comprehension was addressed at all, the vast majority of classroom time devoted to it was actually focused on what she termed assessment, either in the form of teacher oral questions or in the form of worksheets that assessed but did not teach comprehension. More recent research has documented that little has changed in terms of this emphasis. ${ }^{2}$ In addition to the continuing ubiquity of verbal teacher questioning (Nystrand, 1997), typically following an initiationresponse-evaluation sequence (Mehan, 1982), contemporary versions of teacher questioning sequences include practices such as giving sample standardized reading tests and providing multiple choice computer drill on books through programs such as Accelerated Reader (cf. Thompson, Madhuri, \& Taylor, 2008).

Another way the comprehension-as-outcome orientation is enacted is through item teaching, ${ }^{3}$ where teachers provide students with information aimed at enabling the production of certain understandings. Students are taught vocabulary and content knowledge, for example, on this premise: if students have a robust vocabulary and appropriate background knowledge, they will be able to interpret texts correctly. Research in this area has postulated a general effect of vocabulary instruction on assessed comprehension. It has also focused on specific populations of students, such as English

\footnotetext{
${ }^{2}$ I in no way mean to suggest that all teachers privilege this tradition; there are teachers who deliberately teach against the grain, and some teachers who emphasize comprehension-as-outcome do so in response to external mandates and pressure rather than internal persuasion.

${ }^{3}$ I borrow this term from Reading Recovery (e.g., Pinnell, 1985). Its use in Reading Recovery primarily focuses on item teaching (versus teaching for strategies) in word identification, which is somewhat different from how I am using the term here, given my focus on comprehension. My use of this term is related to but broader than the term's use in descriptions of teaching "to" the test, where it refers to drilling students on items that are similar to those that students will encounter in a subsequent test (e.g., Popham, 2001).
} 
Language Learners and socioeconomically disadvantaged students, as well as on the development of specific academic vocabulary (e.g., Baumann, 2009; Beck \& McKeown, 2007; Lesaux, Kieffer, Faller, \& Kelley, 2010).

Perhaps the most prominent proponent of teaching background knowledge in the service of comprehension is E.D. Hirsch, who has asserted that teaching reading comprehension is primarily about preparing students to understand the vocabulary and content they will encounter in texts they read: "We need to adopt a more accurate, less formalistic view of reading, one that grasps the degree to which coherent content in the curriculum is in itself a reading comprehension program -in fact, the most effective one yet devised" (Hirsch, 2005, pp. 185-186). His Core Knowledge curriculum pursues this end by organizing student literacy learning around carefully sequenced knowledge children are believed to need to know in order to understand what they read (Datnow, Borman, \& Stringfield, 2000). For Hirsch (2005), vocabulary plays a pivotal role, though content knowledge also includes conceptual knowledge and understandings beyond the word level.

Comprehension-as-outcome is the object of focus in much of the recent large-scale research on reading. For example, a recent series of articles appearing in the Educational Researcher all addressed the question of research methodologies in large-scale research on reading in elementary settings (Connor et al., 2009; Croninger \& Valli, 2009; Pianta \& Hamre, 2009; Rowan \& Correnti, 2009). Each of these studies was concerned with how to improve classroom reading instruction by tying it to outcome measures of comprehension achievement. It is also important to note that comprehension-as-outcome approaches are not exclusively reserved for the reading of nonfiction text in classrooms: literature instruction with fictional and other literary text frequently relies on comprehension-as-outcome pedagogy as well (Nystrand, 1997).

\section{Comprehension-as-Procedure Pedagogy}

If comprehension-as-outcome pedagogy is most concerned with readers (re)producing certain readings, comprehension-as-procedure pedagogy is most concerned with producing readers who undertake their reading in prespecified ways. Comprehension strategy instruction is one key way in which this happens; for example, in reciprocal teaching, students are taught to predict, generate questions, summarize, and clarify as they read (Palincsar, 1986). The idea behind teaching comprehension strategies is straightforward:

\footnotetext{
Strategy instruction provides students with their culture's best secrets about how to obtain academic success, strategies many students either would not discover at all or would discover only after a great deal of frustration and failure. (Harris \& Pressley, 1991, p. 395)
}

Increasing attention has been paid recently to teaching students specific disciplinary ways of reading, also coming from a comprehension-as-procedure orientation. For instance, Wineburg's (2001) work in the domain of history teaching stems from such an orientation. Having documented that novice readers of history pay attention to different aspects of text than historians do, he argues that history teachers should explicitly teach ways of reading, such as sourcing, that are used by skilled historians. Other disciplines have developed analogous curricula premised upon helping students appropriate disciplinary ways of reading (Moje, 2007; Rabinowitz, 1987).

Some disciplinary reading practices may allow for differing interpretations; for example, different historians may have dramatically different readings of a historical text, and still rely on the same practices 
in undertaking those readings (Gottlieb \& Wineburg, 2011). But when a reader generates a meaning that does not conform to the right set of disciplinary practices, that reading is unacceptable, from a comprehension-as-procedure orientation. One example (from Wineburg, 2001) would be an adult reader, Ted, who read an 1863 historical document that provided a religious argument in favor of slavery. Because Ted applied a contemporary "presentist" lens on racism and multicultural understandings, seeing such categories as static and "unchanged across space and time" (p. 106) rather than historicizing the document as a historian might do, his reading is characterized by Wineburg as problematic.

\section{Expressivist and Dialogic Comprehension-as-Sensemaking Pedagogies}

Comprehension-as-sensemaking refers to the hypothesizing that a reader undertakes as $\mathrm{s} / \mathrm{he}$ wrestles with textual meaning - the active exploration of possibilities for meaning. Comprehension-assensemaking is something that all readers do, even in classrooms that favor particular readings (comprehension-as-outcome) or ways of reading (comprehension-as-procedure). But, when a teacher treats this kind of intellectual work as generative regardless of whether it aligns with her own thinking or ways of reading, $\mathrm{s} / \mathrm{he}$ is proceeding from a comprehension-as-sensemaking orientation. That openness is what crucially distinguishes this pedagogy from comprehension-as-outcome or comprehension-asprocedure pedagogy. Indeed, children (and other novice readers) may engage in textual hypothesizing that leads them to radically different understandings than those held by their teacher for a given text. For example, a Latino fourth grader, Manuel, while reading a passage about tarantulas, considered a line of text that read as follows: "Hairy Mygalomorphs are known by scientists as primitive spiders. They have existed for millions of years, yet have changed very little" (McGinty, 2002, p. 7). Manuel made the following claim about textual meaning:

\footnotetext{
"Right here, I think with the 'million years,' 'millions of years,' I think, like, spiders can live for a million years and that's how long scientists have been studying them. For millions of years, to get used to them and to get a lot of information and facts about them, so they can, like, tell us, so they can tell us which ones are deadly and which ones are not deadly."
}

Although Manuel's interpretation was decidedly different from that of his teacher, he was actively engaged in constructing meaning from the text - thoughtfully interpreting the phrase "they have existed for millions of years" - and he successfully arrived at a meaning that, for him, fit the text. That is, he was engaged in sensemaking. Manuel could be engaged in such sensemaking regardless of the pedagogical focus of the teacher (i.e., even when the teacher is emphasizing comprehension-as-outcome or comprehension-as-procedure). But, when a teacher honors this kind of intellectual work and treats it as generative, $s$ /he is proceeding from a comprehension-as-sensemaking orientation. Such a focus on students' textual thinking regardless of correctness stands in contrast to the previous orientations I have described. Admittedly, it can be seen as radical, particularly when adopted within the context of disciplinary text. ${ }^{4}$ Accepting such textual hypothesizing without trying to twist students' thinking toward a particular "right answer" is often particularly challenging for teachers (Aukerman, 2008).

Even where instruction does honor student sensemaking, it does not always proceed from the same pedagogical assumptions. Indeed, I identified two primary traditions within comprehension-as-

\footnotetext{
${ }^{4}$ For an elaborated discussion of how Manuel's teacher responded in a way that valued his sensemaking and sought to have it refract with those of his peers, see Aukerman, 2008.
} 
sensemaking pedagogy. The first frequently traces its lineage to reader response (Rosenblatt, 1982) ${ }^{5}$; I call it expressivist comprehension-as-sensemaking pedagogy (cf. McCormick, 1994). For example, during classroom readalouds, young readers may be invited to express their diverse reactions to texts; there is no "wrong" interpretive response (Sipe, 2000). And, indeed, the forms these reactions take vary considerably, as Sipe (2000) documented in his taxonomy of young children's responses. Important, though, if the focus is truly on comprehension-as-sensemaking, is that there is no "right" or "wrong" interpretive response to text. Student interpretations, whatever these are, are welcomed, nurtured and celebrated. Yet, because expressivist comprehension-as-sensemaking pedagogy does not identify a major role for the interplay of different readers' interpretations, it treats reader interpretations as substantially self-contained reader-text relationships.

The other major tradition privileging comprehension-as-sensemaking often traces its lineage to Bakhtinian views on language and interaction; I call it dialogic comprehension-as-sensemaking pedagogy. Like expressivist comprehension-as-sensemaking pedagogy, it privileges students' textual ideas regardless of "rightness." But readers are also expected to engage with each others' often differing accounts of what texts say. In this tradition, texts come to mean through a reader's anticipation of and response to the unfolding ideas encountered in how others have read and discussed the present (as well as previous) texts. Thus, teachers believe that students' ideas will transform classroom discourse, other students' understandings, and even their own understandings of text; thus, they pose questions aimed at better understanding student ideas and helping these develop and collide (Aukerman, Belfatti, \& Santori, 2008; Nystrand, 1997). For example, in the following conversation (cf. Belfatti, 2012), Manuel's classmate Jorge had begun to make sense of a nonfiction text called Sand (Prager, 2006) with a hypothesis that sand could be made from rocks, but not from coral. As the conversation proceeded, he reread part of the text, and the teacher asked the group to discuss the sense they were making of it:

$\begin{array}{ll}\text { Jorge: } & \text { Sand made from coral and shells form the whitest of white beaches. } \\ \text { Teacher: } & \text { So what does that mean? } \\ \text { Ned: } & \text { It has to be made out of coral 'cause it says, "made from coral and shells." But coral is very sharp. I mean, } \\ & \text { if you pick up a sharp coral, you can cut yourself on it. It's like glass. It's like if you have a broken piece of } \\ & \text { glass, you can cut yourself on it. That's how coral is. But if you dropped a glass, it breaks. } \\ \text { Teacher: } & \text { I thought Jorge was saying it wasn't made of coral, so l'm getting confused. } \\ \text { Jorge: } & \text { Sand cannot be made from coral because, like you said, it's so easy to break, like glass. You can just pick it } \\ & \text { up and throw it on the ground. Sand cannot be made from coral because, like I said before, coral, all's you } \\ & \text { got to do is toss it on the ground, and it will break. Rock, it takes a hard time to break, so when you break it, } \\ \text { Teacher: } & \text { probably, it take you like a lot of chances to break it, when you break it, it turns into sand. } \\ \text { Jorge: } & \text { Rocks. } \\ \text { Teacher: } & \text { And sand to you [Ned] is made of? } \\ \text { Ned: } & \text { Coral. } \\ \text { Teacher: } & \text { And sand to you [Manuel] is made of? } \\ \text { Manuel: } & \text { Coral. } \\ \text { Teacher: } & \text { Say more. }\end{array}$

\footnotetext{
${ }^{5}$ While reader response in its initial forms primarily emphasized student expression, reader response pedagogies have also taken on the more dialogic forms I discuss in the following paragraph. Thus, some teachers who see themselves as teachers who value reader response might be enacting dialogic rather than expressivist comprehension-as-sensemaking pedagogy.
} 
In this conversation, the teacher's primary concern was not whether the students were coming to an understanding of the text (or of sand formation) that matched her own. She wanted to have a conversation in which she and the students worked together with these ideas as they refracted and evolved (Belfatti, 2008), and her statements ("I'm confused"; "I thought Jorge was saying it wasn't made of coral"; "Say more") were oriented toward having students expand on their thinking and engage with each other's. As she did so, Ned could work through how his understanding of the words did not quite align with his understanding of the properties of coral and of sand, exploring the fit of ideas that did not, for him, quite fit together; Jorge could appropriate Ned's words about coral and use them to support his idea that countered Ned's assertion; and she herself learned to see the text in a different way. ${ }^{6}$

Dialogic comprehension-as-sensemaking pedagogy is not a matter of simply nurturing and celebrating student understandings, but rather of engaging students in dialogue about text in which understandings are transformed through encountering the understandings of others; even when students read alone, they will be engaging with a plethora of possibilities as they make sense of text. From a dialogic perspective on comprehension-as-sensemaking, then, neither a text's meaning, nor the way in which a student arrives at meaning for a text, are predetermined: they are surprises, to use Matusov's (2009) term, that unfold in refraction with other voices that are also working at sensemaking (Bakhtin, 1981).

\section{Monologism and Dialogism in Comprehension Pedagogies}

Some form of what is called dialogue undoubtedly takes place in classrooms oriented toward the other pedagogical orientations, too - those that privilege comprehension-as-outcome, comprehension-asprocedure, or expressivist comprehension-as-sensemaking pedagogy. Yet, dialogic comprehension-assensemaking pedagogy is the only pedagogical orientation described here that is fully dialogic as pedagogy in the Bakhtinian sense: it is the only one that sees meaning-making as fundamentally unfinished, contingent work that centrally depends on the refraction of multiple voices. Comprehensionas-outcome pedagogy makes little or no room for multiple perspectives, favoring a ready-made, monologic view of meaning. Comprehension-as-procedure pedagogy offers a bit more room for readers to engage with text in divergent ways. But, because it allows for only certain ways of reading to count as legitimate, the approach is still dogmatic, in Bakhtinian terms (1984), aimed at reducing or eliminating the element of surprise that students' sensemaking might offer.

And what of expressivist comprehension-as-sensemaking, where students' sensemaking is seen as valuable? Expressivist comprehension-as-sensemaking offers space in the classroom for multiple perspectives, and in some cases acknowledges dialogic reader stances vis-à-vis the text itself, such as children "talking back" to the text (Sipe, 2002). It may also acknowledge the intertextual nature of reader response by identifying how previous readings of different texts "speak" in the reading of a current text (Sipe, 2001). For these reasons, I see it as epistemologically more related to dialogic comprehension-assensemaking than either comprehension-as-outcome or comprehension-as-procedure pedagogies. Yet, within expressivism, the refraction and interanimation of multiple readers' ideas (or of multiple competing voices within a single reader) is not necessarily fostered, and often remains unacknowledged: sensemaking is treated as a relationship with a text, rather than as a relationship that also centrally involves other readers and other voices. For this reason, expressivist comprehension-as-sensemaking pedagogy tends to overlook the socially contingent and emergent nature of meaning-making (cf.

\footnotetext{
${ }^{6}$ While this transcript excerpt was selected to illustrate a way in which a teacher used language to engage with her students' textual ideas, it is important to note that students in this group also directly engaged with each other. Indeed, it was typical for the students challenge and address each other directly. For elaborated examples and analysis of such talk, see Belfatti (2012).
} 
McCormick, 1994); opportunities for dialogic responsiveness among readers in such classrooms tend to be incidental rather than anticipated, orchestrated, and honored.

\section{Some Caveats}

Because sensemaking may initially appear amorphous, I will elaborate on what I mean, then develop my critique of what I perceive as the current outcome-driven focus in comprehension pedagogy. Before I do so, though, I should note several key aspects to how I have applied this terminology. In any classroom there will be students who make textual hypotheses (comprehension-as-sensemaking), arrive at understandings their teachers prefer (comprehension-as-outcome), and apply particular strategies to their reading that can be named and taught (comprehension-as-procedure) - sometimes simultaneously. My schematic is thus not intended to distinguish between what students are doing as they make sense of text, but rather to offer a way of talking about what teachers are pedagogically emphasizing as they seek to support novice readers.

In addition, it is important to note that what a particular pedagogical practice gets called in no way guarantees that the practice will necessarily fall within a particular orientation. The word dialogic appears particularly slippery in this regard. Whitehurst's (1999) dialogic reading intervention among preschool children focuses on discussion, but it does so in explicit service of getting children to arrive at certain understandings, without necessarily emphasizing children's ideas as valuable and important regardless of "rightness." So Whitehurst's work would be categorized in the above schematic as primarily oriented toward comprehension-as-outcome.

Even some of the research discussed by Wilkinson and Son (2011) in their recent review of discussion approaches they characterize as dialogic, such as Questioning the Author or Instructional Conversations (Beck, McKeown, \& Blake, 2009; Goldenberg, 1992/1993) do not necessarily share the premise central in dialogic comprehension-as-sensemaking, that meaning is responsive, emergent and in flux. Though Wilkinson and Son themselves acknowledge that "the product of comprehension - meaning - is not stable" (p. 359), Questioning the Author and Instructional Conversations do not create any explicit space for student understandings that differ from those of the teacher; they illustrate well how discussion might serve as a vehicle for having students achieve the right fixed meaning (comprehension-asoutcome). Thus, while discussion-based approaches may be particularly conducive to dialogic comprehension-as-sensemaking pedagogy, they are not equivalent concepts.

I should also note that the kinds of divisions I have made are tidier than such divisions in the world of practice, since teachers may well juxtapose and juggle different pedagogical orientations. For example, many language arts teachers ask students to keep double-entry journals where students record, in separate columns, events from and reactions to a text: if the first column is about getting at a single "right" meaning for the text, and the second column is about personal sensemaking, then the format would reflect a simultaneous commitment by the teacher to both comprehension-as-outcome and comprehension-as-sensemaking pedagogies. And a teacher who centrally values comprehension-asprocedure might at times engage students in discussion because she genuinely wants to hear their ideas, just as a teacher who centrally values comprehension-as-sensemaking might sometimes steer students toward particular understandings.

Recognizing this messiness, though, does not mean that the distinctions become irrelevant. The central question to be answered in thinking about what orientation underlies a pedagogical practice is how the reader is primarily being positioned vis-à-vis the text: Is the reader positioned as one who should extract a pre-established meaning or range of meanings (comprehension-as-outcome)? As one who must 
apply pre-determined techniques (comprehension-as-procedure)? As someone whose sensemaking is conducted in an individual, idiosyncratic way that primarily involves the reader and text in direct relationship with each other and thus does not need to match that of the teacher (expressivist comprehension-as-sensemaking)? Or, finally, as someone whose textual hypothesizing is dialogically contingent, emergent - important and valuable for what it is and for what it is becoming as it refracts with other textual hypothesizing (dialogic comprehension-as-sensemaking)? While it is possible that a classroom practice might straddle more than one of these, even such a practice might end up privileging one pedagogical orientation over another. For example, if a teacher evaluates a double-entry journal according to how well the student got "the facts" of the text down, but offers little commentary or response to the column recording student responses beyond checking off whether the column has been completed, the practice fundamentally reflects a comprehension-as-outcome pedagogy despite its small nod to expressivist sensemaking.

\section{Defining Sensemaking}

\section{Meaning, Sign, Text}

In order to develop what I mean by sensemaking, I will first describe how I am using a few other terms, including meaning and sign. Voloshinov (1973) proposed that a sign is something that exists as a material reality (such as a word) that "reflects and refracts another reality" (p. 9). Kress (1997) describes one such moment when he tells of a 4-year-old who looked at a piece of toast into which her father had bitten, and proclaimed that he had made it "like a crocodile"' (p. 87). The bitten-into toast is just food until the child draws a relationship between the toast and a crocodile; in that moment it becomes a sign.

For Voloshinov, "Meaning is the expression of a semiotic relationship between a particular piece of reality and another kind of reality that it stands for, represents, or depicts" (1973, p. 28). Meaning thus resides neither within a sign (e.g., the piece of toast), nor in any reality that might be described by that sign (e.g., an actual crocodile). Rather, meaning is relational:

\footnotetext{
Meaning is a function of the sign and is therefore inconceivable (since meaning is pure relation, or function) outside the sign as some particular, independently existing thing. It would be just as absurd to maintain such a notion as to take the meaning of the word 'horse' to be this particular, live animal I am pointing to. Why, if that were so, then I could claim, for instance, that having eaten an apple, I have consumed not an apple but the meaning of the word 'apple.' A sign is a particular material thing, but meaning is not a thing and cannot be isolated from the sign as if it were a piece of reality existing on its own apart from the sign. (p. 28)
}

I am primarily interested in meanings that are developed in relation to texts - representations involving symbols and/or images deliberately arranged to evoke meaning for a reader who will treat them as things that mean. ${ }^{7}$ Such texts, for example, might be picturebooks, algebra problems, or tweets. While texts vary widely in their genre, use and in the range of meanings that a given reader sees as acceptable, all texts exist in order to mean. What human beings do as they read, then, is always about relating text to another reality - a reality that of course may be conceptual (e.g., the notion of freedom) and/or imaginary (e.g., Quidditch) as well as purely concrete and visible. In relating the text to one reality rather than to another, the reader is making an active semiotic decision. It is this act of decision-making,

\footnotetext{
${ }^{7}$ I acknowledge that it is also possible to read things as texts that were not deliberately arranged to evoke meaning, as I might if I study the shapes of clouds and decide on meanings for them. Such readings are not the focus of this paper.
} 
of establishing one relationship between text and reality rather than a different one, that constitutes sensemaking.

\section{The Reader's Context}

Readers, of course, never undertake sensemaking in a vacuum. Although the signs themselves may appear internally, they are responsive not just to the text but also to the reader's context (cf. Nystrand, 1986; Rommetveit, 1974). But what, exactly, do I mean by a context? According to Cole (1995), there are two important ways in which context has been characterized. In the first characterization, individuals are surrounded by a static context that serves as a container - and causal force - for their actions. An alternative view of context sees it as something that is continually reconstituted: individuals and their contexts mutually shape one another. In this view, which I share, contexts are treated "not as static givens, dictated by the social and physical environment, but as ongoing accomplishments negotiated by participants” (Miller \& Goodnow, 1995, p. 8).

Although this idea of context is helpful, even scholars who adopt this more dynamic view have sometimes been silent on another critical question: Context according to whom? The experiencing of a context is never neutral, but rather represents one subjective (albeit negotiated) perspective - one that determines which aspects are available and described. The moment an actual described context comes into play (rather than the abstract idea of context), the context becomes characterized by someone's perspective. Even when two individuals negotiate a "shared" context, for example, during a classroom literacy event, their relative positions as participants in that event differ - making it likely that their senses of the context will differ as well (Aukerman, 2007; Dyson, 1999b). Context is thus in some important sense heteroglossic, irreducible in any honest way to a unified phenomenon or perspective. The scholarly decision of how to represent a context when describing an event is thus always ideological.

Some scholars have articulated how different perspectives on context may be taken up - and why they matter. For example, an outsider may mark different aspects of what is happening than an insider in a given community. Watson-Gegeo (1992) describes what she calls a "vertical context," involving larger institutional structures. Such a context, she points out, "may be poorly understood or even unknown to the interactants," unlike a "horizontal context" that involves more immediate circumstances, events, and interactions (p. 53). Although researchers often lean in the direction of analyzing vertical contexts, Hymes (1972) makes a case for foregrounding the experiences of those actually using the language when studying language in use: "To understand language in its social context requires understanding the meanings that social contexts and uses of language have for their participants" (p. xviii, emphasis added).

In the analytic unpacking of sensemaking that I undertake here, I will, like Hymes, foreground a local, participant perspective on the meaning of context. I believe, moreover, that it is noteworthy that different participants, including readers of the same text in the same classroom, will experience context differently. Foregrounding the reader's understanding of the context makes visible that the inseparable reading of text and context takes place from a uniquely situated perspective for each reader. Because it is this situated perspective that I seek to understand, I emphasize what I call the reader's context. The reader's context (whatever its omissions and idiosyncrasies) is de facto the context that the reader reads while s/he is reading a text; this context, the reader's "internal representation of the context that the text enters," crucially shapes and is shaped by the reader's reading of the text (Witte, 1992, p. 288). I wish to be clear that the reader's context is never static, nor is the reader ever free of social shaping as s/he interprets that context. Rather, the reader's context is emergent, constantly impinged upon by circumstances and negotiated with other social actors, including the text's author. As each succeeding 
clause in a paragraph is read, for example, the reader's sense of the context is renegotiated (cf. Rommetveit, 1974).

\section{Interest and Social Purpose}

Readers are not passive perceivers of contexts; they have particular orientations toward what they experience that figure into their sensemaking. Kress (1997) has used the term interest, which I adopt here, to describe the orientation of attention that a reader brings to an experience of sign-making (or, I would add, of sensemaking); it is interest that determines what aspects of the text are foregrounded in a reader's reading of the text. Kress develops the idea of interest in ways that challenge one prevailing view of the term as something personal and asocial, instead arguing that interest "has physiological, psychological, cultural and social origins" (p. 11). The social (and, I would add, dialogic) aspect of interest is particularly pivotal:

\footnotetext{
Interest is a composite of my experience; but it is also a reflection of my present place .... I stand here now, in a social place, in a physical place. My experience, personally constructed out of my incessant readings through all my life, makes me assess my present position, and its potentials and responsibilities. It makes me read my immediately present social environment, now at this moment in a certain way. (p. 90)
}

Highly related to the idea of interest is the broader idea of the reader's social purposes, what readers are "after" as they read and engage with others around texts (cf. Dyson, 2002). Social purpose encompasses what an individual seeks to accomplish (through reading, but also through other practices); social purposes are multiple, socially configured and continuously re-established. Even though the two are not identical, one's social purposes when reading a particular text are likely to play a major role in one's interest, and vice versa. For example, as a high school student, my interest in The Red Badge of Courage (Crane, 1993) was heavily driven by a desire to locate every possible sexual innuendo (in a text typically not known for these). This interest was connected to social purposes that included wanting to rile the English teacher who had assigned the text, and seeking to portray myself in particular ways to my peers in the class. Both interest and social purposes play integral roles in shaping how readers make sense of text.

\section{Social, Cultural and Semiotic Resources}

Readers also engage with social, cultural and semiotic resources (cf. Dyson, 2002) in the service of the sensemaking work that they do. Broadly speaking, whatever a reader draws upon (consciously or unconsciously) in the process of figuring out what a text means would be such a resource: as I define it, a resource is a resource because it is treated as such by the reader. Resources are social because they involve relationships with others; cultural because they are imbued with the values and practices of particular communities; and semiotic because they support and transform the meanings being made. The reader stands in dialogic relationship with these social, cultural and semiotic resources, reconfiguring and hybridizing (Dyson, 1999a) them in the work of establishing new meanings that are nonetheless never "created from scratch" (Matusov, 2009, p. 120).

What constitutes a resource in deciding on meaning for a text depends on the reader's context, social purposes, and interest at a particular moment in time. Such resources may be interpersonal (e.g., the kid I think is a good reader who is seated next to me), environmental (e.g., letter-sound spelling cards on the wall, the dictionary), or intrapersonal (e.g., knowledge of letter sounds; prior experiences with fruit bats; strong beliefs about what reading is and is not good for; an ascribed identity as a good daughter). 
Since knowledge and experience are developed through relationships with others, and because what is around us is socioculturally constructed, even resources that I have described as environmental or intrapersonal have sociocultural, dialogic dimensions.

\section{Sensemaking and the Sensation of Not Understanding}

What happens during reading, then? A reader dialogically engages with available social, cultural and semiotic resources to create meaning for a text, meaning that is bound up in her/his interest and social purposes as that reader simultaneously makes sense of the context. Seen in this light, sensemaking is the reader's work in the service of a subjective commitment to certain semiotic possibilities over others, that is, toward the "actualization of a decision" (Bakhtin, 1990, p. 28) that resolves for a text to mean one set of things and not another for that reader. When that subjective commitment to certain semiotic possibilities adequately accounts for the reader's interest, given that reader's present social purposes and sense of the context, the reader has understood the text. But, in order for a reader to resolve for a text to mean one thing and not another, the reader must come to see certain semiotic possibilities as internally persuasive:

\footnotetext{
Internally persuasive discourse - as opposed to one that is externally authoritative -- is, as it is affirmed through assimilation, tightly interwoven with "one's own word." In the everyday rounds of our consciousness, the internally persuasive word is half-ours and half-someone else's. Its creativity and productiveness consist precisely in the fact that such a word awakens new and independent words, that it organizes masses of our words from within, and does not remain in an isolated and static condition. .... More than that, it enters into an intense interaction, a struggle with other internally persuasive discourses. (Bakhtin, 1981, pp. 345-346)
}

In terms of sensemaking, meaning can be internally persuasive only if the reader is able to a) wrest the newness of unfamiliar text into her/his own ongoing dialogue with available, often competing and polyphonic, semantic possibilities (born of active engagement, even struggle, with her/his available social, cultural, and semiotic resources); and b) make a subjective commitment to some of these possibilities over others at a particular moment in time.

Conversely, the sensation of not understanding occurs when a reader encountering a text finds it so unclear that $\mathrm{s} / \mathrm{he}$ is unable to commit to a set of semiotic possibilities that satisfy her/his interest in it. When I recently read an obtuse tax code document while doing my taxes, I could piece together partial understanding, but I was still left with a frustrated sensation of not understanding. I never did have a confident sense that I had understood it well enough, given my interest in disambiguating how to complete my tax return as I should. Although I eventually chose a course of action based on my best guess, I was never entirely internally persuaded (Bakhtin, 1981) of the meaning I had created on which that pragmatic decision hinged. My sensation of not understanding does not mean I was not sensemaking - I most certainly was, as my intellectual work was very much in the service of trying to make sense - but it does mean that my sensemaking did not produce a (to me) satisfactory resolution of the semiotic possibilities that accounted for my interest: I did not resolve meaning.

It is important to realize that sensemaking does not, and probably should not, always yield clear resolution for the reader. One may simultaneously juggle multiple semiotic possibilities (and many unresolved questions) as one makes sense of a text. And all resolution is provisional in any case: even a resolved meaning may un-resolve or re-resolve differently at a later point in time. Still, it is important to acknowledge the subjectively different experiences of a reader whose sensemaking becomes 
overwhelmed by a sensation of not understanding - to the point of giving up on the sensemaking as I eventually did with the tax return document - versus one who encounters sufficient resolution to keep wondering and keep at it. Readers who regularly do not feel in a position to resolve meanings of texts for themselves often feel unsuccessful as readers and become dependent on the meanings others assign to texts (cf. Aukerman, Chambers Schuldt, \& Moore Johnson, 2012). I believe it is a pedagogical responsibility of teachers to support students sufficiently in their efforts at sensemaking that students continue to see themselves as capable of resolving meaning, for example, by offering texts that challenge but do not overwhelm the reader.

At the same time, traditional comprehension assessment is not the most reliable way to identify such texts. A number of comprehension assessments, such as the Developmental Reading Assessment (Beaver, 1997), designate a comprehension-related "frustration level" for texts where students provide explanations for what is going on that diverge from the institutional bounds - a comprehension-as-

outcome measure. Such texts are presumed to be too hard for the reader. While it may be true that both the teacher and the student would be frustrated in a classroom setting where this student was expected to produce a reading that was considered within the institutional bounds for such texts, what would be frustrating under those circumstances would be the expectations for a particular, narrow reading - not necessarily the text itself. While there may be valid diagnostic reasons for such a test (full disclosure: I administered many in the past myself), I believe that a "frustration level" designation should apply only to those texts where students see themselves as incapable of fruitful sensemaking - a designation that depends on close observation of the student with a variety of kinds of text rather than the results of a comprehension-as-outcome measure. ${ }^{8}$

\section{Alien Judgments and Institutional Boundaries}

When the textual meanings readers create for themselves become visible to others through how they talk about, write about, or act on their sensemaking, those around them commonly make judgments about those meanings, often on the basis of how they themselves have made or are making sense of the same text(s). A lover struggles to explain that the true intent of a hastily scrawled text message differed from how a hurt loved one received those words; a scathing review of a scientific article is found unconvincing by an editor who has read the same article more generously; two friends who have read a book share a laugh as they recognize that both were rooting for the villainous character rather than the "heroine." Reading is a fundamentally evaluative task, and part of what we do as readers is evaluate how convincing the readings we encounter around us are, and to seek to convince others when we prefer for them to share our meanings for the texts we have read in common (Aukerman, 2007). In the course of encountering alien judgments about one's own sensemaking, readers will sometimes realize a need to closely re-examine previously resolved meanings; sometimes they will not. Either way, bumping up against other readings (both in external and internal dialogue with others) is part of what makes reading inevitably social, dialogic, and never definitively finished.

Yet, while judgments about one another's sensemaking can have a fruitful role in dialogic comprehension-as-sensemaking pedagogy, I believe these judgments often become problematic when they become fused with authoritative discourse (Bakhtin, 1981), as appears to be frequently the case in classrooms. Because judgments about how other readers have made sense of text are frequently bound up in historical conventions and social status, the judgments of those with the most institutional and social capital (Bourdieu, 1986; Luke, 1996) - usually the teacher, in a classroom - are enormously powerful.

\footnotetext{
8 Indeed, in one classroom I observed regularly where dialogic sense-making pedagogy was the norm, students frequently tackled and resolved meaning from texts that would have certainly been "frustration level" text for them according to traditional comprehension leveling schemes. Used to having their sensemaking matter, they were in no way put off by the text difficulty.
} 
Those with such capital have the power to enforce what they see as the institutional boundaries. These boundaries, based on their own, inevitably limited, sense of what is plausible, can come to determine what counts as legitimate comprehension. While institutional boundaries are inevitably fluid and contextually contingent (with that contingency driven by the teacher's sense of the context), certain meanings attached to texts can become reified as correct, wrongly seen as the "one true" meaning of the text.

Yet, it is important to keep in mind that readers who read a given text within the institutional bounds do not share an identical understanding of that text, for they do not share identical interests, social purposes, or social, cultural and semiotic resources. As when different spotlights, beamed from many angles, are directed at the "same" location on a stage, the light and resulting shadows cast by each readers' sensemaking is a different one. For example, Kramsch (2000) found that adult college students who were asked to summarize a story about an immigrant produced a wide range of summaries that revealed subtly different meanings the story held for these readers. Kramsch focused on differences that could be linguistically parsed; even her analysis did not get at differences in subjective experience that went deeper than that, as when two readers who use the same term, e.g., "immigrant," imbue that word with different subjective meanings, meanings bound to bear traces of the different subjective experiences in which that term has come to its present meaning for each reader (Kress, 1997). Such differences in light and shadow, reflective of inherent dialogism, undercut any posited monologic purity of what is considered institutionally in bounds. Yet, these differences may not become visible in classrooms. As Matusov (2013) has noted, "Agreement is a special discursive activity of ignoring the differences and the local uniqueness of both context of the meaning and the meaning making process and abstracting similarities" (p. 6).

Often more visible are moments when a student says something that reveals an understanding of the text sufficiently distinctive that it is not recognized as plausible by those with more institutional capital: I call such sensemaking reading outside of the institutional bounds. Take the sentence, John was hit by Mary. For a reading to be considered within the institutional bounds, the reader would typically need to designate Mary as the hitter and John as the one who got hit. But the parameters of what gets designated as an institutional understanding usually extend further. For example, a teacher in the United States might expect that students identify Mary's hitting as inappropriate.

What counts as within bounds in a classroom usually depends on what the teacher finds plausible - which in turn is dependent on the teacher's sense of both the text and the context. A teacher with a feminist take on John and Mary might, or might not, expect her kindergarten students to see John and Mary in the same light. And the teacher's sense of what is within bounds is not her/his own individual construction, but has been shaped by parameters which have become salient to her/him through many conversations in which s/he has previously been engaged; ultimately, what counts as good reading for a given reader is historically and culturally (over)determined (cf. Freebody, Luke, \& Gilbert, 1991).

Sometimes there may indeed be good reason for wanting readers to identify and respect institutional boundaries, no matter how socially constructed and arbitrary those may be. For example, the stakes of reading within the institutional boundaries may be high indeed: mortality rates for elderly patients with high assessed literacy levels are half that of those with low assessed literacy levels, 18.9\% compared to $39.4 \%$, respectively (Baker et al., 2007); there are marked differences in patient medical knowledge depending on assessed literacy level that could account for this gap (e.g., Williams, Baker, Parker, \& Nurss, 1998). Arguably, readers should learn to read the labels on their prescription medication 
to determine dosage as their doctor intended, and to come to see other possible readings as ones they need to put aside when they act on their reading of the medication instructions.

What is important to realize is that, as a sociocognitive semiotic process, sensemaking that resolves a meaning for a text inside the institutional bounds is utterly indistinguishable from sensemaking that resolves a meaning for the text outside of the institutional bounds - even if the consequences of such readings have different stakes attached to them. Readers may choose different courses of action on the basis of their readings; subsequent judgments about those meanings as they become visible to others may differ; other people's judgments may shape how a reader comes to think about the text and about her/himself as a sensemaker over time. But, when Manuel understood a text to mean that a single tarantula could live for millions of years, or when Jorge argued that sand could not be made from coral, they were engaged in sensemaking no more and no less than their peers across the table who believed the text meant something else. They brought to bear the social, cultural and semiotic resources currently at their disposal in order to make sense of the text exactly as a reader who generates a reading recognized as within the institutional bounds might.

Moreover, readings such as theirs are also not wholly out of bounds when examined more closely. When Manuel read the passage about tarantulas, his reading appeared to roughly align with that of his teacher in the sense that he identified it as pertaining to spiders and ascribed temporal significance to the "million years" mentioned in the passage (and thus it could be described as within bounds in that respect). But his reading did not match his teacher's view that the time frame referred to multiple generations of spiders rather than to a single spider's life span (and thus it could simultaneously be described as out of bounds in that respect). When I use the term reading outside of the institutional bounds throughout the rest of this paper, I will be referring to situations in which the out-of-boundsness is in some way salient to the teacher (even if the teacher recognizes the student's reading as a valid one - it is possible to see institutional boundaries as salient without agreeing with them or considering the students' reading less valid). But I assume that such sensemaking might be well within bounds when the focus shifts to different aspects of the meaning being made.

Of course, a student may be driven to say something about a text that does not reflect meaning $\mathrm{s} /$ he has resolved through sensemaking but is rather an attempt (often a blind guess) to meet a teacher's demands despite being confused. These students are likely looking for ways to satisfy the teacher and/or save face rather than reveal that they are experiencing the sensation of not understanding (cf. Hall, 2009). Readers who are experiencing the sensation of not understanding (whether or not they seek to hide that) are likely to experience the sensemaking process in profoundly different ways from those readers who are resolving meaning through sensemaking (even when outside of the institutional bounds). These differing sensemaking experiences call for different pedagogical responses, I believe, and yet the distinction between these experiences are not necessarily pedagogically recognized because the boundary that generally gets all the attention is the arbitrary one between readings that are in and out of bounds.

Because comprehension-as-sensemaking pedagogy makes room for readings whether they are in or out of bounds, the arbitrary institutional line between in and out of bounds does not assume the importance that it does in comprehension-as-outcome and comprehension-as-procedure pedagogies. In a dialogic comprehension-as-sensemaking classroom, the teacher will not cast off her/his own subjective sense of what is plausible ( $\mathrm{s} / \mathrm{he}$ too is a reader who resolves meaning, after all), and may remain quietly aware of what might get counted as institutionally in and out of bounds within certain reading circles. But $\mathrm{s} /$ he recognizes this subjective sense as potentially limiting, and strives to encounter students' 
perspectives in part as a way to become less beholden to the assumptions that have previously guided her/his reading of the text. Such a position is not only pedagogically coherent, but is more theoretically defensible than an exclusive focus on reading within the institutional bounds, as I argue below.

\section{Questioning the Predominant Emphasis on Reading within the Institutional Bounds}

\section{Meaning: Affixed in Text?}

The emphasis on reading within the institutional bounds generally relies on one of two ways of conceptualizing meaning-making. The first takes the commonsensical view that the meaning of a text is affixed and predetermined, in the text, to be extracted by the reader. This position is common in comprehension-as-outcome pedagogy: readers are supposed to arrive at a given predetermined meaning, affixed by the author, to be extracted by the reader. But, in comprehension-as-procedure pedagogy, there is also a tendency to treat meaning as affixed in the text: if there is a single text-inherent meaning, then it follows that a predictable sequence of moves could enable a reader to arrive at that meaning (Olson, 1977; Pressley, 2000).

Yet, the insights of the schema theorists (e.g., Anderson \& Pearson, 1984; Rumelhart, 1981), starting more than 30 years ago, render this conceptualization of meaning problematic. Schema theory built a strong case that meaning is always shaped by what the reader brings to a text. A range of studies have established that readers from different cultural backgrounds make different kinds of meaning from the same text, that readers' purposes alter the meaning that is made, and that different readers attend to different dimensions of the same text to construct meaning (Goetz, Schallert, Reynolds, \& Radin, 1983; Prichard, 1990; Steffensen, Joag-dev, \& Anderson, 1979). Although schema theory itself has been critiqued, and alternative theories proposed (e.g., Kintsch, 1998; McVee, Dunsmore, \& Gavelek, 2005; Sadoski, Paivio, \& Goetz, 1991), all of the more well-developed theories of comprehension assert an active role for the reader that, when taken to its logical conclusion, renders the simple meaning-extraction view of reading comprehension problematic.

But not all of those who assert an active role for the reader have fully moved past a view of reading as meaning extraction, and attempts to move past it can remain stuck in a compromise position that is theoretically inconsistent. For example, the RAND Reading Study Group (2002, pp., p. 91) is one of the few prominent documents aimed at influencing reading research that is bold enough to provide a definition for comprehension at all: "We define reading comprehension as the process of simultaneously extracting and constructing meaning through interaction and involvement with written language" (p. 91). While intriguing, this definition conceptually falls short. Construction implies the creation of something new using available materials; extraction implies that a pre-existing object is isolated. It remains unclear what it would mean for the same thing (meaning) to be extracted and constructed simultaneously.

At the very least, the relationship between construction and extraction needs systematic elaboration in order to be tenable, yet the RAND report does not clarify the relationship beyond stating: "We use the words extracting and constructing to emphasize both the importance and the insufficiency of the text in comprehension" (RAND Reading Study Group, 2002, p. 11). Extraction implies that at least some unadulterated aspects of meaning are taken from the text alongside moments when one is building understanding through the lens of the known. But, if this view is to be accepted, which aspects of meaning would reside in the text, and which would be constructed? If unadulterated pieces of meaning did exist, that would mean that what the reader brings to the text is irrelevant to that part of the meaning for that reader. As intuitive as it might seem to posit some aspects of meaning as text-inherent, it is not a 
coherent theoretical stance - and it is entirely inconsistent with Voloshinov's (1973) argument that meaning be seen as the expression of a semiotic relationship that is not to be located within the sign itself.

\section{Meaning: Cultural Codes to be Recognized?}

There is an alternative, and somewhat more defensible, theoretical position from which it is possible to privilege reading within the institutional bounds. I will call this position social constructionism, following Nystrand's usage (1992). From a social constructionist point of view, one can still treat meaning as something stable even if one does not wish to argue that meaning is extracted in some unadulterated way from a text where it was previously affixed. Social constructionists accept the premise that meaning is constructed by readers whose existing understandings play an integral role in that construction process. However,

\footnotetext{
Social constructionism represents discourse as the informed activity of members of particular interpretive communities.... In this view a text interpretation is "canonical" and discourse is "normal" to the extent that each is consistent respectively with the premises and speech patterns of its parent community. (Nystrand, 1992, p. 158)
}

According to this perspective, writers produce texts according to culturally determined reading codes, and readers in turn are expected to read according to these codes. Smagorinsky has developed one of the more thorough explications consistent with this view of meaning-making; he argues that "readers who lack enculturation to reading codes will not have access to the meaning potential that they are inscribed to suggest" (Smagorinsky, 2001, p. 143). Reading from within a culturally determined set of codes still allows for some divergence of textual understanding. But Smagorinsky proposes that readings made without access to this important set of codes lie outside the "transactional zone" (2001, p. 143) where institutionally sanctioned understandings are produced. Thus, the primary goal of teaching students to read for meaning (for social constructionists) is to help them learn to access to the right codes, since these codes are what enable the production of institutional understandings: the job of the teacher is to socialize students into the kinds of knowledge and ways of reading that enable them to join a particular reading community (cf. Rabinowitz \& Smith, 1998).

Although a theoretic improvement, the pedagogical implications of the social constructionist emphasis on meaning as code-dependent do not appear dramatically different from those that see meaning as text-inherent; indeed, when examining empirical research studies on comprehension, it is often difficult to tell which of these two positions is in play. For social constructionists, meaning may not be fixed in texts, but meaning is essentially fixed in codes. These codes might manifest themselves as bits of knowledge (comprehension-as-outcome), for example, knowing that certain markers indicate that a particular character is being portrayed as gay in a novel from the 1930's, or they might manifest themselves as more sophisticated processes in which readers engage (comprehension-as-procedure), for example, deciding on what themes underlie a Shakespearean tragedy (Rabinowitz \& Smith, 1998).

Either way, mature readers are unlikely to accept meanings that fail to draw on the right codes, according to the social constructionists. Thus, the right range of meanings and ways of reading are not open to question, just as they are not open to question when meaning is seen as residing within the text itself. Because codes are seen as stable repertoires drawn upon by readers and writers, meaning is still reified as a given that must be correctly reproduced. 
Nystrand has critiqued the social constructionist perspective; he argues that social interactionism ${ }^{9}$ more adequately captures the actual reading/writing people do than social constructionism, describing the distinction between the two as follows:

For social constructionists, texts and text interpretations function semiotically by representing or instantiating the norms of the group.... By contrast, for social interactionists texts and text interpretation function by intermingling and mediating the purposes and interests of conversants [writers and readers]. (Nystrand, 1992, p. 163)

Social interactionism, as Nystrand understands it, proceeds from the Bakhtinian (1981) premise that reading and writing are fundamentally heteroglossic. That is, while there are certainly centripetal forces, that "tend toward unity and system which make communication and codification possible," there are also always centrifugal forces that "foster the diversity, multiplicity, and heterogeneity which characterize actual discourse" (Nystrand, 1992, p. 164). These centrifugal forces are not impediments to be overcome, but rather represent the stuff of actual readers' grappling with text - a mess of competing possibilities and purposes that do not necessarily behave nicely as meaning is being constructed.

As a result, meaning is never stable, nor "irrevocably fixed" (Nystrand, 1986, p. 35) - not in the text, and not in pre-established cultural codes either. Instead, meaning is negotiated - first, as the writer "balances her own intentions with what she anticipates will be the expectations of her readers," and again "as the reader interprets the text in light of his own assumptions about the author" (Nystrand, 1992, pp. 164-165). Meaning is configured as this reciprocal relationship between reader and writer is negotiated in particular contexts of use, given their respective interests, and is premised on "the joint expectations of the conversants that they should understand one another" (Nystrand \& Himley, 1984, p. 200) - the fundamental contract between writers and readers. If so, then the idea of valuing a reader's sensemaking only if it produces a reading that is within particular institutional bounds is profoundly problematic.

I argue that Nystrand's social interactionism reflects a more realistic sense of what actual readers do as they wrestle meaning from text. To be sure, sensemaking will be deeply informed by the work of other readers - inevitably, and as it should be. But what makes a posited meaning for a text internally persuasive (Bakhtin, 1981) to a reader is not faithful acceptance of a predetermined meaning inscribed in cultural codes, but rather having a posited meaning adequately account for the text in light of the reader's assumptions about the author and the author's purposes. And what shapes those assumptions is involvement in dialogue during the reading with multiple others, past and present voices that are (or have sought to become) internally persuasive to the reader through dialogue.

So the semiotic choices the reader makes in determining meaning are still ultimately premised on her/his dyadic relationship with the author - what s/he understands that person to be doing as s/he makes her own sense of the text. Even if a reader makes her/his choice for a social purpose explicitly bound up in wanting to function as a member of a particular interpretive community, and even if s/he seeks to produce readings within certain institutional bounds that will help establish that membership, resolved meanings will still be about that reader's assumptions about the author's intentions. Indeed, each reader's sense of what the institutional bounds are for a reading are driven by that dyadic reader-

\footnotetext{
${ }^{9}$ It is important to note that Nystrand's definition of social interactionism differs from the interactionism often associated with George Herbert Mead (1962), who emphasized the social nature of the mind but did not necessarily perceive of it as in heteroglossic dialogue with others.
} 
author relationship as it enters into contact with the polyphony (Bakhtin, 1984) of the reader's ongoing dialogues with others.

\section{The Enduring Appeal of Seeing Textual Meaning as Fixed (and a Response)}

Thus, when pedagogies place a premium on students being able to arrive at shared institutional understandings, ones that depend on having access to a particular interpretive community's ways of reading, they treat meaning as fixed, not negotiated. In doing so, they somewhat misrepresent the act of reading. They foreground what readers "should" do rather than foregrounding what readers actually do.

There are real reasons for privileging reading within the institutional bounds. Even those like myself who lean toward social interactionism would generally acknowledge that centripetal forces (Bakhtin, 1981) in constructing meaning from text do exist - forces that often move readings in the direction of institutionally sanctioned meaning. And since these centripetal forces may be treated largely as stable interpretive communities to which readers must adapt their readings (both in classrooms and in other social circles), there is an argument to be made that social constructionism is more suited as a practical model for thinking of reading comprehension in classrooms than social interactionism is.

I mean that, although social interactionism is a fuller depiction of what readers actually do, social constructionism still may represent a fuller depiction of the image of reading that is pedagogically and socially most in play. And image matters. To the extent that academic environments rely on a notion of stable interpretive communities (albeit ones that are reified, idealized, and not fully representative of the ways in which readers actually read), it is possible to make a case for teaching reading as the social constructionists do, as if it were a matter of accessing the correct codes to arrive at socially predetermined meanings to texts. Regardless of the extent to which it may be theoretically problematic to presume that textual meaning is fixed, reading within the institutional bounds does matter socially, after all.

Because such reading is by definition associated with cultural capital, there is enormous appeal to basing reading pedagogy on the social constructionist premise that it should lead students to read within the institutional bounds. And one can point to real consequences beyond the classroom of not being able to construct such a meaning. Reading a bus schedule in a highly idiosyncratic way may mean that the reader misses the bus. In the case of some legal documents (e.g., restraining orders, Miranda rights), maintaining institutional boundaries on what constitutes a legitimate reading - and making sure that the understandings of those critically affected by those documents fall within the institutional bounds - can protect those who are most vulnerable. Reading a public safety notice, traffic sign, or instructions for a medical operation in ways that do not fall within institutional parameters which the author was assuming can result even in death. And there is also the less dramatic but still convincing perspective of writers on the matter: typically a writer wants to be understood by her/his reader; those who write articles for academic publication would certainly take issue with the notion that any reading of their own work is equally valid (cf. Smagorinsky, 2001).

Perhaps for these reasons, reading within the institutional bounds has assumed a privileged place in comprehension pedagogy, and a comprehension-as-outcome orientation functions as the overarching evaluative and pedagogical apparatus in most conventional reading classrooms (Durkin, 1978-79; Nystrand, 1997). Indeed, with a few exceptions, outcome-oriented measures that privilege reading within the institutional bounds are the basis for determining what constitutes successful reading teaching. For example, even Nystrand's (1997) large-scale study of dialogic discourse in English classrooms linked classroom opportunities to engage in such thinking with outcome measures premised 
on institutional understandings. So, although the pedagogical premises of the study were focused on comprehension-as-sensemaking, the study's measurement was focused on comprehension-as-outcome: the importance of comprehension-as-sensemaking pedagogy was empirically justified by its superior ability to enable students to read within the institutional bounds when compared with instruction that did not focus on students' sensemaking.

I have no quarrel with the proposition that some attention to reading within the institutional bounds is warranted, but I do take issue with the pedagogical primacy of that focus. An overarching emphasis on the efficacy of teaching, defined in this one way, fails on the theoretical grounds I have laid out thus far: it idealizes reified notions of textual meaning that ignore the heteroglossic nature of sensemaking, and it fails to acknowledge the dyadic relationship of reader and writer during sensemaking. But what is even more troubling is that a primary emphasis on comprehension-as-outcome also fails on ethical grounds.

Indeed, one important perspective that talks back to the utilitarian premises surrounding an emphasis on institutional understandings is voiced by Willis (2008). She argues that, when educators privilege certain institutional understandings, they actually privilege the ideology of the culturally dominant group. Such a position, she maintains, "misses or underestimates relationships and associations with, and in, the world in which ideas are formed, acted upon, and silenced," an ideologically charged world in which texts, and ways of reading, are associated with power and often with White privilege (Willis, 2008, p. xxiv). Even if one were able to nail down important reading codes precisely (as the social constructionists would have us do), these will never be either neutral or equally relevant and sensible to all readers.

Some social constructionists concur but argue that it would be a disservice to cultural minority students not to give them access to the very codes they need for success (cf. Delpit, 1988; Rabinowitz \& Smith, 1998). Willis, though, makes the case that this premise (which assumes only the reader and not the system can change) rests on "a narrow and inadequate foundation" (Willis, 2008, p. 217) - a foundation that fails to acknowledge the ideological ramifications of reifying institutional understandings and of penalizing those readers who fail to produce them.

\section{Toward an Ethic of Honoring Sensemaking}

\section{Making Comprehension-as-Sensemaking the Crux of Reading Pedagogy}

I propose, then, that reading comprehension pedagogy should shift from its current focus on institutional understandings to a primary emphasis on eliciting, illuminating, and juxtaposing students' sensemaking: special attention to reading within the institutional bounds should become subordinate to that. Indeed, conventional designations of what counts as in and out of bounds may need to be rethought or even abandoned. Rather than thinking about all pedagogical practices in the domain of reading as being in the ultimate service of comprehension-as-outcome, educators should think about pedagogical practices (including those that might be characterized as comprehension-as-outcome or comprehensionas-procedure pedagogy) as being in the larger service of supporting students' comprehension-assensemaking.

Such a shift initially may seem naïve. Why should a teacher respect all sensemaking, including sensemaking that might be (to her/his mind) way off the mark, even in a science or history classroom? Why should a reading that is outside of the institutional bounds be accorded the kind of hearing that has generally been reserved for a reading that matches the teacher's read on what is plausible? One 
possible answer to these questions is that reading comprehension pedagogy should attend to a far broader set of outcomes (e.g., the student's sense of self-efficacy; the student's awareness of multiple perspectives; the student's sense of commitment to her/his own ideas, etc.). Focusing on comprehensionas-outcome, seen from this perspective, may mislead educators by priming them to see the wrong thing as the most important. It is possible, when a broader set of outcomes is considered, that what students learn in a classroom where all of their textual ideas are treated as worthy of examination will be more valuable than what students learn in a classroom where respect is accorded to only those readings that align with those of the teacher.

But I argue that something even more important is at stake here. The work humans do in the service of making sense of their worlds - and that certainly includes the sense they make of texts - is entitled to a critical level of respect that should be unassailable. By unassailable, I mean that this respect, in the context of the classroom, should come before other pedagogical goals a teacher might have in mind, including getting students to produce particular kinds of readings. Respect for the reader certainly does not mean the absence of challenge, nor even the absence of consequences when the reader resolves meaning for a text that is not plausible to others. But it does require, first, that the teacher hear what each reader does with a text as fundamentally bound up with that person's identity, agency, and humanness. Thus, the teacher needs to acknowledge that all textual meanings, including the teacher's own, are contingent, limited, and open to evolution from the perspectives that others bring.

It follows that the teacher should wholeheartedly strive to make sense of the textual sensemaking of her/his students, and to engage with that sensemaking, answering it in a way that honors it. Such engagement with student sensemaking, I propose, should be seen as a fundamental ethical obligation of a teacher: anyone who does the human work of trying to make sense of text should be entitled to a place at the table. That some resolved meaning will be factually wrong, or even on occasion morally questionable, does not mean the work of sensemaking can be dismissed.

I make this case because I maintain that our textual sensemaking is a fundamental part of our humanity. As human beings, we are born with a prelinguistic capacity to mean, to communicate with others who are doing their meaning with and around us; even young babies engage in dyadic, nonmimetic exchanges of meaning through proto-signs and gestures well before conventional adult-like language takes root (Halliday, 2005). And this non-mimetic drive to understand and be understood follows children into later experiences with text (Kress, 1997). Indeed, there is evidence that students in the same classroom engage in sensemaking in different ways, even when reading the same text (Santori, 2008). These semiotic decisions reflect interests and social purposes connected to who the reader takes her/himself to be and what it is about the text and the context that matters to her/him. Thus, a failure to respect a reader's textual sensemaking is a failure to honor that part of the reader's humanity - a failure to acknowledge that even a novice reader constructs textual meaning out of the ideational stuff of who s/he is.

Of course, if respect for textual sensemaking is something that we as human beings all owe one another, then students also have an obligation to strive to make sense of the textual sensemaking of others, including the sensemaking of their peers, of their teachers, and of other more distant readers and writers. In other words, students, no less (and no more) than their teachers, should take a dialogic stance vis-à-vis the voices they encounter around them. It is to this standard, then - one that places value on the sense each of us, as human beings, endeavors to make of text - that teachers should hold themselves and their students accountable during classroom encounters with text. 
If taken seriously, of course, the teacher's ethical obligation to privilege sensemaking is also a pedagogical one. Teachers should seek out pedagogical practices where student sensemaking plays a pivotal role and eschew practices that undermine respect for student sensemaking, even if such practices might have apparent benefits when viewed through a comprehension-as-outcome or comprehension-asprocedure lens. Consider, again, the definition of sensemaking that I offered earlier: the reader's work in the service of a subjective commitment to certain semiotic possibilities over others, that is, toward the "actualization of a decision" (Bakhtin, 1990, p. 28) that resolves for a text to mean one set of things and not another for that reader. In a setting where comprehension-as-sensemaking pedagogy is primary (e.g., Aukerman, 2007; Mohan, 2008; Santori, 2008), one would thus see the teacher:

a) Inviting students to read texts where divergent understandings are likely to become visible, ones that will challenge but not overwhelm the students who will be making sense of them;

b) Putting students in situations where they exercise their own textual authority rather than consistently positioning the teacher as the only textual authority (for example, by withholding evaluation of student responses, whether these lie within or outside perceived institutional bounds);

c) Expecting that all classroom participants take the sensemaking of others, within and beyond the classroom, seriously (for example, by asking students to consider closely the contributions of a low-status student; or by asking them to engage with a published critique of a text being studied);

d) Facilitating frequent opportunities where students' sensemaking and resolved meanings become visible, develop, and intermingle (for example, by facilitating dialogue rich with teacher uptake and open discussion among students, particularly when divergent understandings begin to become visible);

e) Encouraging students' awareness of how others respond to the meanings they resolve, and also of how these responses might matter given the purposes that are at stake for them (for example, by pointing out disagreements or places where a course of action chosen on the basis of one's sensemaking - such as following a written series of steps to conduct an experiment - might be rewarding or disappointing to the reader);

f) Making additional social, cultural and semiotic resources available for the reader to do her/his work, and encouraging students to make creative use of such resources (for example, by supporting students' decoding proficiency or vocabulary knowledge; or by pointing out how her/his own cultural blinders might have made her/him initially unaware of certain textual possibilities); and

g) Inviting students to consider potential new purposes and interests as they engage with text (for example, by inviting students who are particularly drawn toward pictures in the text to consider how engagement with the words might open different doors for them as readers; or by suggesting that stories can be read with a feminist or critical lens as well as for the content of the story).

It is important to note that honoring student sensemaking does not mean that student understandings are treated as fully-formed creations, beyond critique. Because sensemaking is a social undertaking, not an individualistic one, a dialogic pedagogy that honors student sensemaking also 
highlights the ways in which sensemaking is transformed through dialogue; multiple competing understandings are par for the course.

\section{Comprehension-as-Sensemaking Pedagogy and Reading within the Institutional Bounds}

Can teachers legitimately invite students to consider readings that are institutionally within bounds without truncating or undermining respect for students' ongoing sensemaking? I believe that the teacher should carefully consider whether and how any special attention to the institutional bounds (as the teacher perceives these) could contribute to students' ongoing work as sensemakers; s/he should exercise considerable restraint before issuing such an invitation. In many cases, such an emphasis is unnecessary (at best) or counterproductive (at worst), either because special attention to reading within the institutional bounds would serve no critical pedagogical purpose (e.g., there is no compelling reason that Manuel needs to accurately estimate the lifespan of tarantulas right now), or because students would explore those institutional bounds with each other in the absence of targeted teacher intervention. I trust that, in many cases, students will invite one another to consider readings that are institutionally in bounds, and I do not underestimate the persuasive power of such invitations by other students. Indeed, students may come to a more nuanced sense of institutional bounds (and how they see those bounds) through free-flowing dialogic discussion with their peers rather than through deliberate teacher intervention. Still, there may be selected times when the teacher can productively issue invitations for students to consider readings within the institutional bounds. The challenge in those cases is for the teacher to facilitate the exploration and examination of those institutionally sanctioned readings - and the stakes involved in accepting or rejecting them - rather than dictating that students adopt the readings because they are "right."

For example, in one classroom where the teacher sought to organize instruction dialogically, I observed a teacher-facilitated discussion in which second graders passionately discussed their differing responses to a particular test item on a previously completed multiple choice reading test mandated by the district. The discussion focused initially - and primarily - on the students' varied reasons for the choices they had made. But the teacher also presented the answer that "the test-makers" had privileged, and then asked the students to consider: why might the test-makers have privileged that answer? Was that privileging legitimate and fair? Did students still prefer their own responses? Why or why not? In this way, the institutional bounds themselves became deliberately and overtly dialogized, and students' sensemaking was not subjugated to the "right" answer.

\section{Potential Barriers to Dialogic Comprehension-as-Sensemaking Pedagogy}

Comprehension-as-sensemaking pedagogy does not represent some kind of educational utopia, of course: even where teachers have the desire and the freedom to take it on, such pedagogy is hard work and will face its own set of difficulties. Inevitably, the teacher will have to make choices around how to orchestrate conversations, and may not always be as successful as s/he would like in having all student perspectives unpacked. The polyphony (Bakhtin, 1984) of the give and take, the lack of clear right answers, and the upsetting of the intellectual apple cart may feel uncomfortable to some students. For example, with multiple, divergent student purposes at work, and varying understandings of the context, some students might feel frustrated by peers taking the conversation in a direction that feels to them too loosey-goosey and extra-textual, while their peers feel equally frustrated that those students are trying to rein in the conversation in ways that feel too textually constraining to them.

Furthermore, teachers committed to dialogic comprehension-as-sensemaking pedagogies may need to contend with student hierarchies that position certain high-status students as the textual 
authorities and devalue the voices of other students, in effect reinscribing a problematic evaluative apparatus into classroom discourse. In other classroom settings, students may be reluctant to engage critically with one another's perspectives (enacting a detached, expressivist comprehension-assensemaking perspective on each other's ideas). How does a teacher honor the purposes these students bring while at the same time pushing them toward dialogue in which students transform their own and each other's thinking about text through their talk? And at what point, if at all, should a teacher introduce divergent textual perspectives when students genuinely share views on a text that might be problematically uncritical, narrow, or racist/sexist/homophobic, and no student challenges such views? I acknowledge that pedagogical complexities abound. Yet, as I see it, these complexities do not absolve educators of the obligation to work at creating classroom cultures where dialogic comprehension-assensemaking pedagogy becomes central; indeed, they make it more urgent for educators to develop, share, and research varied ways in which teachers can approach and work through the difficulties, and to learn from those teachers who already embrace dialogic comprehension-as-sensemaking pedagogy.

\section{Reconceptualizing Pedagogies}

I also reject a simple, dichotomous view of pedagogy that assumes that a classroom that privileges comprehension-as-sensemaking should never borrow practices associated with comprehension-as-outcome or comprehension-as-procedure pedagogies. If the purposes for these pedagogies are substantively reimagined, associated classroom practices can play a supporting role in a classroom where dialogic comprehension-as-sensemaking pedagogy is central. For instance, teaching vocabulary, currently approached from a simple comprehension-as-outcome orientation in most cases, can instead be seen as offering additional social, cultural and semiotic resources that will be available to (and inevitably transformed by) the reader as s/he seeks to make sense of text - but only if such instruction is embedded in a curriculum in which comprehension-as-sensemaking pedagogy predominates. The reframing might be phrased as follows, from the teacher's perspective: I am introducing my students to unfamiliar vocabulary relevant to a particular text they will be reading, not primarily in order that they read within the institutional bounds as I perceive those, but rather so that they might have additional resources available for evaluating that text as they work to decide on their meanings for it. I hope that this move helps the text not feel so overwhelming that the struggle to understand turns the students away from the sensemaking. I know that my students will understand even the definition I provide in varied ways, and that the variation will enrich the work we do together to make sense of the text.

Similarly, the teaching of disciplinary ways of reading, which is currently approached from a comprehension-as-procedure orientation in most cases, might instead be offered as a way to make additional social, cultural and semiotic resources available to the reader for her/his sensemaking. Or disciplinary ways of reading might be reframed as a ways of paying attention to the sensemaking that other people do, and of potentially trying on different kinds of interests. A teacher might pose the issue to her/his students in this way: Here is how a particular historian read this passage we discussed yesterday - let us take that person's sensemaking seriously by examining what is behind it. How might your own reading of the passage be different if you were making this historian's assumptions about texts when you read? How does that alternative way of reading feel to you?

Thus, I reconceptualize the practices associated with comprehension-as-outcome and comprehension-as-procedure pedagogies as provisional semantic offerings, made to students with the expectation that students will inevitably transform those offerings as they bring them into contact with their current and future understandings. When reconceptualized as offerings, the other pedagogies become part of a teacher's invitation to further the ongoing interpersonal and intrapersonal dialogue about textual 
meaning, rather than fixing a desired endpoint (traditional comprehension-as-outcome) or becoming the sine qua non (traditional comprehension-as-procedure) of reading comprehension. Of course, if comprehension-as-outcome and comprehension-as-procedure pedagogies are re-envisioned as offerings that support an ongoing, larger focus on comprehension-as-sensemaking, then they must remain subordinate to that focus. And teachers must be ready to let them go in those moments where they threaten to truncate or undermine respect for students' ongoing sensemaking about texts.

\section{Envisioning the Letting Go}

I close, then, by describing a teacher who engaged in just such a letting go. Ms. Christensen, a fifth grade teacher in an ethnically diverse urban classroom, made comprehension-as-sensemaking pedagogy the lynchpin of her science instruction, which involved close readings of science texts, handson inquiry activities, and hour-long discussions of student thinking (Mohan, 2008). Yet Ms. Christensen also had moments in her curriculum where she gently guided or provoked students toward experiences that might enable them to read within the institutional bounds. She explained the importance she placed on her students being able to grapple with their own and each other's understandings of science content in this way:

I think that they need to hear people making sense of what they're seeing. They need to hear explanations, whether they're right or wrong, initially because that sort of discussion-entertaining back and forth, entertaining ideas and suggestions, and ideas and opinions-I think that's an important part of it-the give and take. But I also think that during the discussion if we're aiming toward something, for instance, the transparent, translucent, opaque activity, l'm going to be sort of corralling them toward these final working definitions, so out of the discussion l'm hoping will arise an [scientific] explanation for the phenomena that they were exploring. (Mohan, 2008, p. 50)

Although Ms. Christensen's words here might sound much like a teacher who was incorporating a comprehension-as-sensemaking orientation in the ultimate service of comprehension-as-outcome, what distinguished her teaching was that, even when she seemed to be guiding students toward a particular understanding, it was not her preconceived idea of that understanding, but the students' sensemaking within the conversation, that remained most important. For example, definitions were not ends in themselves, but rather "working" definitions that students could appropriate as the classroom dialogue around ideas continued.

And, despite her language of "corralling" student understandings, Ms. Christensen in fact allowed students' intellectual work to transform her own understandings - there was some mutual corralling going on, if you will. In one conversation about a text describing evaporation and condensation, she posed the question: What drives the water cycle? The students generated a number of different hypotheses (air, water, sun) and discussed these: they developed and revised these multiple views based on their linguistic and scientific understandings, drawing on textual evidence as well as personal experience and analogy. When Ms. Christensen returned to the question on a subsequent day, she acknowledged to the students how their ideas had reshaped her own thinking:

I don't think I realized or appreciated just exactly how deeply you would think about it and how difficult and complicated the question was. But as I've listened to your questions, I've come to feel that maybe there really isn't an answer. The reason that I asked the question in the first place, was because in your book when it came to what we were reading, "the role of the sun", it said on page 79. You want to open up your book. "The role of the sun", and we read through this. I'm waiting for you to get your book opened up to page 79. 


\begin{abstract}
"Evaporation and condensation in earth's atmosphere depends on the heat energy of the sun. The sun heats up the water on the surface of lakes, rivers, oceans and even puddles. Water evaporates from all these sources adding water vapor to the air. When the sun heats earth unevenly, either from place to place, or from day to night, warm air cools and the water vapor condenses back to liquid water. This movement of water from the surface of the air, surface of the earth to the air and back to the surface is called the water cycle. What do you think drives the water cycle?" And I thought that paragraph made it pretty clear to me just what drove the water cycle. Now after having the discussion that we've had, I see that it's much more complicated than that, and maybe the question is not nearly as important as the discussion that you've had about it. Do we need to come up with what drives the water cycle? Do you think we need to come to a consensus on that? (Mohan, 2008, pp. 62-63)
\end{abstract}

Ms. Christensen did want her students to come to understandings of the science texts they read that were institutionally within bounds, and did see herself as playing an active role in moving students in the direction of those understandings. Yet, even more important to her than having her question answered in the "right" way was the discussion itself, a discussion in which students' textual ideas were of central importance to her and to each other. Ms. Christensen was able to recognize that reading within the institutional bounds (in this case, answering her question about what drives the water cycle with "the sun" as the answer) mattered considerably less than the students' reasons and reasoning as they explored the question and issues at hand. Because she never made comprehension-as-outcome the primary goal, she ultimately let her preferred answer and her need for consensus, both driven by her sense of what was institutionally in bounds, go. She never lost sight of a conviction that the sense students make of texts and of their worlds is what matters most of all during reading. And neither should the rest of us.

\title{
Acknowledgements
}

I extend thanks to the many people who read and commented on various drafts of this manuscript, particularly the thoughtful editors and reviewers, whose ideas I will continue to ponder as I move forward. Monica Belfatti provided helpful feedback and generously allowed me to use unpublished data from her research on dialogically organized conversations about nonfiction picturebooks among fourth graders. Martin Nystrand, Jessica Pandya, Max Vélez and Paige Ware were particularly supportive during the writing process, and their insights, as well as those from various graduate students in my classes, helped shape this piece into its current form. I dedicate this writing to the memory of my beloved colleague, Larry Sipe, whose voice animates and responds to mine even after his passing. Larry, I am still talking with you, and owe you a debt of gratitude for all the conversations you started with me that remain unfinished.

\section{References}

Anderson, R., \& Pearson, P. D. (1984). A schema-theoretic view of basic processes in reading comprehension. In P. D. Pearson, R. Barr, M. Kamil \& P. Mosenthal (Eds.), The Handbook of Reading Research (Vol. 1, pp. 255-291). New York: Longman.

Aukerman, M. (2007). When reading it wrong is getting it right: Shared evaluation pedagogy among "struggling" fifth grade readers. Research in the Teaching of English, 42(1), 56-103.

Aukerman, M. (2008). In praise of wiggle room: Locating comprehension in unlikely places. Language Arts, 86(1), 52-60.

Aukerman, M., Belfatti, M., \& Santori, D. (2008). Teaching and learning dialogically organized reading instruction. English Education, 40(4), 340-364. 
Aukerman, M., Chambers Schuldt, L., \& Moore Johnson, E. (2012). Doing reading: Student understandings of what it means to read in dialogically and monologically organized classrooms. Paper presented at the American Educational Research Association Conference, Vancouver, Canada.

Baker, D. W., Wolf, M. S., Feinglass, J., Thompson, J. A., Gazmararian, J. A., \& Huang, J. (2007). Health literacy and mortality among elderly persons. Archives of Internal Medicine, 167, 1503-1509.

Bakhtin, M. (1981). Discourse in the novel. In M. Holquist (Ed.), The dialogic imagination (pp. 259-492). Austin: University of Texas Press.

Bakhtin, M. (1984). Problems of Dostoevsky's Poetics (V. W. McGee, Trans.). Minneapolis: University of Minnesota Press.

Bakhtin, M. (1990). Author and hero in aesthetic activity (V. Liapunov, Trans.). In M. Holquist \& V. Liapunov (Eds.), Art and answerability: Early philosophical essays of M. M. Bakhtin. Austin, TX: University of Texas Press.

Baumann, J. F. (2009). Intensity of vocabulary instruction and effects on reading comprehension. Topics in Language Disorders, 29(4), 312-328.

Beaver, J. (1997). Developmental Reading Assessment. Parsippany, NJ: Celebration Press.

Beck, I., \& McKeown, M. G. (2007). Increasing young low-income children's oral vocabulary repertoires through rich and focused instruction. The Elementary School Journal, 107(3), 251-271.

Beck, I., McKeown, M. G., \& Blake, R. G. K. (2009). Rethinking reading comprehension instruction: A comparison of instruction for strategies and content approaches. Reading Research Quarterly, 44(3), 218-253.

Belfatti, M. (2008). [Personal Communication].

Belfatti, M. (2012). Contesting nonfiction: Fourth graders making sense of words and images in science information book discussions. Unpublished doctoral dissertation, University of Pennsylvania, Philadelphia, PA.

Bourdieu, P. (1986). The forms of capital. In J. Richardson (Ed.), Handbook of theory and research for the sociology of education. (pp. 241-258). New York: Greenwood Press.

Cole, M. (1995). The supra-individual envelope of development: Activity and practice, situation and context. In J. J. Goodnow, M. P. J. \& F. Kessel (Eds.), Cultural practices as contexts for development. San Francisco: Jossey-Bass.

Connor, C. M., Morrison, F. J., Fishman, B. J., Ponitz, C. C., Glasney, S., S.Underwood, P., . . . Schatschneider, C. (2009). The ISI Classroom Observation System: Examining the literacy instruction provided to individual students. Educational Researcher, 38(2), 85.

Crane, S. (1993). The red badge of courage (New ed. ed.). London: J.M. Dent.

Croninger, R. G., \& Valli, L. (2009). "Where is the action?" Challenges to studying the teaching of reading in elementary classrooms. Educational Researcher, 38(2), 100.

Datnow, A., Borman, G., \& Stringfield, S. (2000). School reform through a highly specified curriculum: Implementation and effects of the Core Knowledge sequence. The Elementary School Journal, 101(2), 167-191.

Delpit, L. D. (1988). The silenced dialogue: Power and pedagogy in educating other people's children. Harvard Educational Review, 58(3), 280-298.

Durkin, D. (1978-79). What classroom observations reveal about reading comprehension instruction. Reading Research Quarterly, 15(481-533).

Dyson, A. H. (1999a). Coach Bombay's kids learn to write: Children's appropriation of media material for school literacy. Research in the Teaching of English, 33(4), 367-402.

Dyson, A. H. (1999b). Transforming transfer: Unruly children, contrary text, and the persistence of the pedagogical order. In A. Iran-Nejad \& P. D. Pearson (Eds.), Review of research in education (Vol. 24). Washington, D.C.: AERA, doi:10.3102/0091732X024001141 
Dyson, A. H. (2002). The brothers and the sisters learn to write: Popular literacies in childhood and school cultures. New York: Teachers College Press.

Freebody, P., Luke, A., \& Gilbert, P. (1991). Reading positions and practices in the classroom. Curriculum Inquiry, 21(4), 435-457.

Goetz, E., Schallert, D., Reynolds, R., \& Radin, D. (1983). Reading in perspective: What real cops and pretend burglars look for in a story. Journal of Educational Psychology, 75, 500-510, doi: 10.1037/0022-0663.75.4.500

Goldenberg, C. (1992/1993). Instructional conversations: Promoting comprehension through discussion. The Reading Teacher, 46(4), 316-326.

Gottlieb, E., \& Wineburg, S. (2011). Between Veritas and Communitas: Epistemic Switching in the Reading of Academic and Sacred History. Journal of the Learning Sciences, 21(1), 84-129. doi: 10.1080/10508406.2011.582376

Hall, L. (2009). Struggling reader, struggling teacher: An examination of student-teacher transactions with reading instruction and text in social studies. Research in the Teaching of English, 43(3), 286-309.

Halliday, M. (2005). Representing the child as a semiotic being (one who means). In J. Foley (Ed.), Language, Education, and Discourse: Functional Approaches (pp. 19-42). New York: Continuum.

Harris, K. R., \& Pressley, M. (1991). The nature of cognitive strategy instruction: interactive strategy construction. Exceptional Children, 57(5), 392-404.

Hirsch, E. D. (2005). Education reform and content: The long view. Brookings Papers on Education Policy, (8), 175-207.

Hymes, D. (1972). Introduction. In C. B. Cazden, V. P. John \& D. Hymes (Eds.), Functions of language in the classroom (pp. i-lx). Oxford, England: Teachers College Press.

Kintsch, W. (1998). Comprehension: A paradigm for cognition. New York: Cambridge University Press.

Kramsch, C. (2000). Social discursive construction of self in L2 learning. In J. Lantolf (Ed.), Sociocultural theory and second language learning (pp. 133-153). Oxford: Oxford University Press.

Kress, G. (1997). Before writing: Rethinking the paths to literacy. London: Routledge.

Lesaux, N., Kieffer, M., Faller, S., \& Kelley, J. (2010). The effectiveness and ease of implementation of an academic vocabulary intervention for linguistically diverse students in urban middle schools. Reading Research Quarterly, 45(2), 196-228.

Luke, A. (1996). Genres of power? Literacy education and the production of capital. In R. Hasan \& G. Williams (Eds.), Literacy in Society (pp. 308-338). New York: Longman.

Matusov, E. (2009). Journey into dialogic pedagogy. Hauppauge, NY: Nova Publishers.

Matusov, E. (2013). Comprehension: A dialogic authorial approach. Paper presented at the Conference of the International Society for Theoretical Psychology, Santiago, Chile.

McCormick, K. (1994). The culture of reading and the teaching of English. Manchester, NY: Manchester University Press.

McGinty, A. B. (2002). The tarantula. New York: Rosen Publishing Group.

McVee, M., Dunsmore, K., \& Gavelek, J. (2005). Schema theory revisited. Review of Educational Research, 75(4), 531-566, doi: 10.3102/00346543075004531

Mead, H. (1962). Mind, self, and society: from the standpoint of a social behaviorist (Vol. The University of Chicago Press). Chicago.

Mehan, $\mathrm{H}$. (1982). The structure of classroom events and their consequences for student performance. In P. Gilmore \& A. A. Glatthorn (Eds.), Children in and out of school. Washington, D.C.: Center for Applied Linguistics.

Miller, P. J., \& Goodnow, J. (1995). Cultural practices: Toward an integration of culture and development. In J. J. Goodnow, M. P. J. \& F. Kessel (Eds.), Cultural practices as contexts for development (pp. 5-16). San Francisco: Jossey-Bass. 
Mohan, L. (2008). Orchestrating productive discussion: A study of dialogic discourse and participation in science classrooms. Unpublished doctoral dissertation, Michigan State University, East Lansing, Michigan.

Moje, E. (2007). Chapter 1: Developing socially just subject-matter instruction--A review of the literature on disciplinary literacy teaching. Review of research in education, 31(1), 1-44, doi:10.3102/0091732X07300046001

National Reading Panel. (2000). The Report of the National Reading Panel. Teaching children to read: An evidence-based assessment of the scientific research literature. Washington, D.C.: National Institute of Child Health and Development, U.S. Government Printing Office. URL: http://www.nichd.nih.gov/publications/nrp/smallbook.cfm

Nystrand, M. (1986). The structure of written communication: Studies in reciprocity between writers and readers. Orlando: Academic Press.

Nystrand, M. (1992). Social interactionism versus social constructionism: Bakhtin, Rommetveit, and the semiotics of written text. In A. H. Wold (Ed.), The Dialogical alternative : towards a theory of language and mind. Oslo: Scandinavian University Press.

Nystrand, M. (1997). Opening dialogue: Understanding the dynamics of language and learning in the English classroom. New York: Teachers College Press.

Nystrand, M., \& Himley, M. (1984). Written text as social interaction. Theory Into Practice, 23(3), 198-207, doi:10.1080/00405848409543114

Olson, D. (1977). From utterance to text: The bias of language in speech and writing. Harvard Education Review, 47, 257-281.

Palincsar, A. S. (1986). The role of dialogue in providing scaffolded instruction. Educational Psychologist, 21(1 \& 2), 73-98, doi:10.1080/00461520.1986.9653025

Pianta, R. C., \& Hamre, B. K. (2009). Conceptualization, measurement, and improvement of classroom processes: Standardized observation can leverage capacity. [Feature Article]. Educational Researcher, 38(2), 109-119. doi: 10.3102/0013189x09332374

Pinnell, G. S. (1985). Helping teachers help children at risk: Insights from the Reading Recovery program. Peabody Journal of Education, 62(3), 70-85.

Popham, W. J. (2001). Teaching to the test. Educational Leadership, 58(6), 16-20, URL: http://centralwisconsinhub.wausaudailyherald.com/assets/pdf/U018904259.PDF

Prager, E. (2006). Sand. Washington, DC: National Geographic Society.

Pressley, M. (2000). What should comprehension instruction be the instruction of? In M. Kamil, P. Mosenthal, P. D. Pearson \& R. Barr (Eds.), Handbook of reading research (Vol. 3, pp. 545-562). Mahwah, NJ: Lawrence Erlbaum Associates.

Prichard, R. (1990). The effects of cultural schemata on reading processing strategies. Reading Research Quarterly, 25(4), 273-295.

Rabinowitz, P. J. (1987). Before reading : narrative conventions and the politics of interpretation. Ithaca :: Cornell University Press.

Rabinowitz, P. J., \& Smith, M. W. (1998). Authorizing readers: Resistance and respect in the teaching of literature. New York: Teachers College Press.

RAND Reading Study Group. (2002). Reading for understanding: Toward a research and development program in reading comprehension. Arlington, VA: RAND.

Rommetveit, R. (1974). On message structure: A framework for the study of language and communication. New York: Wiley.

Rosenblatt, L. (1982). The literary transaction: Evocation and response. Theory into Practice, 21, 268277.

Rowan, B., \& Correnti, R. (2009). Studying reading instruction with teacher logs: Lessons from the study of instructional improvement. Educational Researcher, 38(2), 120. 
Rumelhart, D. E. (1981). Schemata: The building blocks of cognition. In J. T. Guthrie (Ed.), Comprehension and teaching: Research reviews (pp. 3-26). Newark, DE: International Reading Association.

Sadoski, M., Paivio, A., \& Goetz, E. T. (1991). A critique of schema theory in reading and a dual coding alternative. Reading Research Quarterly, 26(4), 463-484.

Santori, D. (2008). "Sense-making -- the heart of the matter": Exploring reading comprehension in various participation structures. Unpublished doctoral dissertation, University of Pennsylvania, Philadelphia.

Sipe, L. (2000). The construction of literary understanding by first and second graders in oral response to picture storybook read-alouds. Reading Research Quarterly, 35(2), 252-275, doi: 10.1598/RRQ.35.2.4

Sipe, L. (2001). A palimpsest of stories: Young children's construction of intertextual links among fairytale variants. Reading Research and Instruction, 40(4), 333-352.

Sipe, L. (2002). Talking back and taking over: Young children's expressive engagement during storybook readalouds. Language Arts, 55(5), 476-483.

Smagorinsky, P. (2001). If meaning is constructed, what's it made from? Review of Educational Research, 71(1), 133-169, doi: 10.3102/00346543071001133

Steffensen, M., Joag-dev, C., \& Anderson, R. (1979). A cross-cultural perspective on reading comprehension. Reading Research Quarterly, 15(1), 10-29.

Thompson, G., Madhuri, M., \& Taylor, D. (2008). How the Accelerated Reader program can become counterproductive for high school students. Journal of Adolescent \& Adult Literacy, 51(7), 550560.

Voloshinov, V. N. (1973). Marxism and the philosophy of language. New York: Seminar Press.

Watson-Gegeo, K. A. (1992). Thick explanation of the ethnographic study of child socialization: A longitudinal study of the problem of schooling for Kwara'ae (Solomon Islands) children. In W. Corsaro \& P. J. Miller (Eds.), Interpretive approaches to children's socialization (pp. 51-66). San Francisco: Jossey-Bass.

Whitehurst, G. J., Crone, D. A., Zevenbergen, A. A., Schultz, M. D., Velting, O. N., \& Fischel, J. E. (1999). Outcomes of an emergent literacy intervention from Head Start through second grade. Journal of Educational Psychology, 91(2), 261-272.

Wilkinson, I. A., \& Son, E. H. (2011). A dialogic turn in research on learning and teaching to comprehend In M. L. Kamil, P. D. Pearson, E. Moje \& P. Afflerbach (Eds.), Handbook of reading research (Vol. IV, pp. 359-387). New York: Routledge.

Williams, M. V., Baker, D. W., Parker, R. M., \& Nurss, J. R. (1998). Relationship of functional health literacy to patients' knowledge of their chronic disease: A study of patients with hypertension and diabetes. Archives of Internal Medicine, 166, 166-172.

Willis, A. I. (2008). Reading comprehension research and testing in the U.S. : undercurrents of race, class, and power in the struggle for meaning. New York :: Lawrence Erlbaum Associates.

Wineburg, S. S. (2001). Historical thinking and other unnatural acts : charting the future of teaching the past. Philadelphia :: Temple University Press.

Witte, S. P. (1992). Context, Text, Intertext: Toward a constructivist semiotic of writing. Written Communication, 9(2), 237-308.

Wolf, S., Carey, A., \& Mieras, E. (1996). "What is this literachurch stuff anyway?": Preservice teachers' growth in understanding children's literary response. Reading Research Quarterly, 31(2), 130157, doi: 10.1598/RRQ.31.2.2 


\section{(cc) EY}

Articles in this journal are licensed under a Creative Commons Attribution 3.0 United States License.

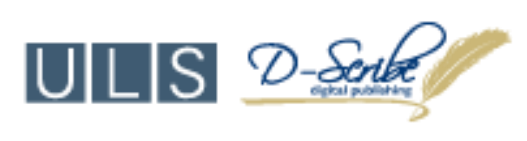

This journal is published by the University Library System, University of Pittsburgh as part of its D-Scribe Digital Publishing Program and is cosponsored by the University of Pittsburgh Press. 